\title{
Examining Navigators' Job Satisfaction in Royal Malaysian Air Force through the Lenses of Herzberg's Motivation-Hygiene Theory
}

\author{
Nurmazilah Mahzan and Ali Zaini Zainal Abidin
}

\begin{abstract}
Many studies investigate job satisfaction and motivation in the workplace using Herzberg's motivation-hygiene factor theory; however, none specifically relate these factors to Navigators in the Royal Malaysian Air Force in which limited promotion is available. This study investigated the factors affecting job satisfaction for Navigators in the Royal Malaysian Air Force. 54 respondents from various operational squadrons and units completed the survey. The factors adapted from Herzberg's Motivation-Hygiene Theory were tested. The motivation factors achievement, recognition, growth, work itself and promotion were found to be significance and dominance in this study whereas policies, flight safety and relationship with leaders were the significant hygiene factors. A multiple regression is also conducted and from result found that career growth is the most significant factor that influence the job satisfaction of Navigators in the Royal Malaysian Air Force.
\end{abstract}

Index Terms-Herzberg's motivation-hygiene theory, navigator's job satisfaction, royal Malaysian air force.

\section{INTRODUCTION}

Job satisfaction plays a vital role in achieving an employee career goals and is equally as important for organisation that works in a team-based environment like Royal Malaysian Air Force (RMAF) or in a workplace comprised of employees who work independently [1]. The best and highly motivated performers of an organisation consistently provide high quality work; maintain a high level of productivity and able to overcome obstacles or challenges. Helping all employees maintain a high level of job satisfaction can help keep employees committed to working hard and contributing as much value as possible to the organisation [2].

The organisation could use a variety of strategies to improve job satisfaction. Leaders and managers who serve within the organisation could help deliver the right messages to engage employees and help them grow within their positions. Job satisfaction could be augmented with incentives, feedback, rewards programs and ensuring that the workplace meets basic needs and requirements for each employee. Common types of motivational tactics include: events that raise employee morale; training and education to help employees learn new skills and grow within their positions; recognition programs to highlight hard work and

Manuscript received February 9, 2014; revised April 27, 2014.

Nurmazilah Mahzan is with the Faculty of Business and Accountancy University Malaya, Kuala Lumpur 50603, Malaysia (email: nurmazilah@um.edu.my).

Ali Zaini Zainal Abidin is with the Royal Malaysian Air Force. reinforcing positive messages during company or team meetings [3].

\section{A. Navigator's Career Path in RMAF}

Navigators are employed in the operational squadrons of RMAF once they have completed their basic Navigator's training whether overseas or locally. Their stay would last a minimum of 15-20 years depending on their progress in the field and their ability to maintain the required operational standard and medical status.

Their career path in the squadron would start from junior Navigator with up to 5 years' experience as a navigator, the more experience Navigators then advanced to become senior Navigator which has the experience between 5 to 10 years, at this stage the Navigators are proficient and qualified to undertake any tasks and missions. The best Navigators then will be selected to undergo an airborne instructional technique in preparation to become a Qualified Navigator Instructor (QNI). They will be employed in various squadrons and a selected few will be posted to become Navigator Instructor in Navigator's school.

A few top performers from QNI will be selected as Standard Checkers and Navigator Examiner. [4]. In many circumstances, not all Navigators would be given the opportunity or have the ability to assume all the above appointments. All the progressions are merely within a squadron or a cross squadron progression. The maximum rank for all these appointments is Major [5], [6].

Even though Navigators have performed and progressed well in various squadrons, they still need to be transferred or to be employed to other departments to give way to junior Navigators to progress in the squadron. The juniors need to progress and the seniors need to be relocated due to the nature of the establishment and appointments in the squadron.

Unlike other officers in the RMAF, Navigators are not being considered to be promoted as a Commander or higher position in the squadron or unit. One of the reasons is the establishment of the organization itself, [5]. The establishments and the appointments in the organisational chart were formulated not favourable to the minority like Navigator, [5]. In the RMAF, Navigators are the minority whom are employed in most of the operation squadrons to carry out their specific duties. In squadron level, their appointments are limited to subordinate commander which will not assume a higher responsibility as compared to other traits, [5]. The highest rank for these responsibilities are Major and the rest of the Navigators in the same departments are equal or below the rank of Major.

The "experienced" Navigators have to be relocated to 
other departments in the RMAF as staff officers and it is inevitable. They have to endure and perform diverse job specifications which are completely unrelated to their expertise. On the other word, they have to re-master. Majority of them who plunged into this group are the senior Major ranks that have already served more than 20 years in the RMAF. They are technically and proficiently eligible for lateral or vertical promotion in the organisation but, their progressions are very limited [5]. As the Navigators become more experience in their job in the organisation, they turn out to be more vigilant in their job. Their awareness on flight safety heightens as they grow older. In many circumstances, military flying operations would involve a very high risk mission that need to be performed without fail. The failure means "no return". For those who had experienced a bad flight or accident would be demotivated and their morale would also be affected. These phenomena contributed to fewer Navigators remain active in flying squadron. They made their way out from active flying by various reasons. At this rank (Major), despite devoting all their effort and commitment to the service, only a few could be considered for higher rank promotion and progression. This is a major dilemma and the most challenging rank as a Navigator in the RMAF. Majority will remain at this rank until their retirement age.

In the workplace, some Navigators feel that they are devalued and unrecognised. They normally don't ask for recognition but they're human which will surely appreciate recognition. Unfortunately, at certain point as Navigator becomes more skilled and competent, the air goes out of their motivational sails and boredom, stress and negativity creep in. They still do their job but productivity flattens and likely decreases. The Navigators may start missing work, arriving late, complaining more, making mistakes, becoming accident prone, and even becoming ill. A number of them resigned prematurely from the service to pursue other jobs [7]. In general, the RMAF loses some of the top talents, conscientious and hardworking employees that would probably drive the organisation to the next level.

\section{LITERATURE REVIEW}

Herzberg [8] in his study on motivation wrote a very famous theory called "The Motivation to Work". This theory of motivation is known as a motivation-hygiene theory and it is based upon the notion that motivation can be split into hygiene factors and motivation factors. Herzberg proposed that in order to determine what motivates workers, one must discover what factors satisfy and dissatisfy them. Herzberg describes and measures job satisfaction in terms of two distinct sets of variables, hygiene and motivational factors Hygiene comprise of factor that influence the work and organizational environment such as policies ,relationship with others, working conditions, relationship with peers , pay, work security and in this research we expanded the work security factor to include flight safety. Herzberg asserted that these factors do not lead to higher levels of motivation but without them there is dissatisfaction.

The second component in Herzberg's motivation theory involves what people actually do on the job and should be engineered into the jobs; employees do in order to develop intrinsic motivation with the workforce. The motivators are achievement [9], [10], recognition [11], career growth or advancement [12], [13], nature of work itself and promotion opportunities [14].

\section{A. Hygiene Factors}

There are many prior research that examine partially or all the hygiene factors proposed by Herzberg's. For example [15] surveys on security contractor job satisfaction by looking at the policies of the organization. Level of Pay or salary is another hygiene factor being previously studied. [16] examine the effects of locally competitive salary supplements and the turnover rate in all North Carolina school districts. The hygiene factor salary was found to be the most important reason for teachers to leave their positions [16].

In Royal Malaysian Air Force, a few studies were conducted on job satisfaction. [13] conducted a study on the job satisfaction of the personnel in the Air Traffic Control. The cross sectional study was conducted to gauge the level of job satisfaction and to identify the main factor that contribute to satisfaction of Air Traffic Controllers in the RMAF. It was concluded that economic rewards and relationship with peers were the significant factors contributed to the overall satisfaction of personnel of Air Traffic Controller.

In the other study conducted by [17], his study on Air Defence Operators focusing on factors from Herzberg's motivation-hygiene theory and personal characteristics. The Air Defence Operators in the RMAF valued salary more than any other factors. The other factors that contributed to the overall satisfaction for them were achievement and responsibility. His study on Air Defence Operators shows that salary is the key factor in keeping them motivated and satisfied.

Other than organizational policy, working conditions, relationship with peers and salary, [18] found another important hygiene factor that influence job satisfaction, which is job security. In their study on employees of the Therapy Centre for Dependent Individuals in Greece, they found that the employees are very concern about the job security.

Further, [17] explore the hygiene factor regarding relationship with leaders and peers. In [19] the validity of Herzberg's Two-Factor Theory of Motivation was tested empirically on foodservice soldiers and logistics officers. This study compares job satisfaction between soldier and officer groups and assesses the effect of Herzberg's motivators and hygiene factors on job satisfaction. It was shown that hygiene factors were more powerful predictors of job satisfaction than motivators. Motivators had a more significant association with logistics officer's satisfaction than hygiene factors. For soldiers, "human supervision" and "independence" factors were ranked first and second for their impact on job satisfaction. In contrast, "achievement" and "working conditions" factors were the two most important motivation factors for logistics officers' job satisfaction [17]. Working condition is indeed an important hygiene factor that influence job satisfaction. In [20] which investigates the relationship between shift work, which is a crucial element of working conditions, and job satisfaction of shift work, the researcher found that rotating shift had detrimental effects on 
certain personal, social, and organizational variables such as psychological well-being, quality of family life, burnout, and job satisfaction.

Interestingly, there is another factor related to working condition that is salient to the flight navigators' job which is flight safety. Airline accident investigations by the Federal Aviation Administration (FAA), the National Transportation Safety Board (NTSB), and research conducted by National Aeronautics and Space Administration (NASA) investigators suggest that "crew or pilot error" has been a critical factor in more than $65 \%$ of U.S. airline mishaps. [21] in their study describe various types of conflict, operational context, phase of flight, operator states, and situations conducive to communication conflicts, risk perception differences and inappropriate resolution strategies in aviation industry. [18] provides comprehensive empirical data on the intricate relations among aging, flight experience, and safety performance. The results indicated that flight safety, as measured by rates of crashes per million pilot flight hours, does not change significantly as pilot's age from their late forties to their late fifties. Flight experience, as measured by total flight time, is a more important determinant of crash risk than aging. Since navigators are concern about safety, this study include flight safety as one of the factors to be tested on its impact to job satisfaction.

\section{B. Motivation Factors}

Whilst hygiene factors address the dissatisfaction that affect employees, motivation factors explore those aspects that make them happy. Herzberg theory identified those factors as achievement, recognition, growth or advancement, work itself and promotion opportunities.

Several studies examined these factors in various different context. For example [18] studied the motivation of physicians and confirmed that achievement, recognition, characteristics of the work, responsibility, and career growth affect their job satisfaction. The study by [22] shows a consistent findings. An online cross-sectional survey was conducted on tenured nurse faculties nationwide to explore reasons why nurse faculty leave or stay as academia. The analysis revealed that the most significant factor influencing retention was professional satisfaction with faculty identity, including the ability to shape nursing practice. Flynn [8] argued that rewards and recognition programs keep high spirits among employees, boosts up their morale and create a linkage between performance and motivation of the employees. HR policies and practices that enhance personal growth and motivate the workforce would secure a durable employee-employer relationship via social exchange process, which brings a win-win situation that benefits both parties in the long run. Foong-ming [23].

Promotion opportunities is also a crucial factor that influence motivation. Tahir [13] asserts that promotions create the opportunity for personal growth, increased levels of responsibility and an increase on social standing.

\section{Job Satisfaction in Royal Malaysian Air-Force}

There are limited studies conducted on job satisfaction related to air force in particular the Malaysia Royal Air Force. [1] described job satisfaction as the degree to which people like the job. They examined the relationship between job satisfaction and stress level among air force military pilots. In another earlier study by [24], performance pay scheme failed to motivate revenue employees in performing their job. The system was said to be corrupted and unfair by the employees causing many workers disgruntled which is an indication of job dissatisfaction.

In a Malaysian scenario, [2] studied the relationship between job satisfaction and absenteeism in the Royal Malaysian Air Force. He studied why personnel in the RMAF involved in absenteeism and he found a few factors contributing to this negative behaviour. The inclination to go absent is directly correlated with job satisfaction of the personnel, in this situation; the low motivated personnel are at higher risk of going absent as compared to the high motivated ones.

\section{Study ObJeCtIVES AND RESEARCH QUESTIONS}

Despite several studies mentioned above, none look at the navigators' job satisfaction in the air force which is facing issues on limited job progression opportunities [5] hence many of them remain in the rank of sergeant major until their retirement age. Therefore, the objective of this research is to identify the hygiene and motivational factors suggested by Herzberg on job satisfaction of Navigators in the RMAF and which of the factors that have the highest impact. Based on the discussion above, there are three research questions (RQ) for this paper which are; RQ1: Which motivation factors that have a high impact on Navigators job satisfaction? RQ 2: Which hygiene factors that have a high impact on Navigators job satisfaction? RQ 3: Which Herzberg's motivation-hygiene factors that have the highest impact on Navigators job satisfaction?

\section{RESUlTS}

\section{A. Demographics}

The data was collected through surveys of 56 samples which were distributed to navigators in all RMAF bases. A demographic analysis was conducted and found that majority of respondents are holding the rank of Major, 41-50 years and diploma holders. Navigators in the RMAF are still dominated by male that have served more than 21 years. Table I shows the detail respondents' demographic.

\section{B. Herzberg's Motivation Factors}

Table II presents the correlation matrix of job satisfaction and Herzberg's motivation-hygiene theory. There was significant positive correlation between job satisfaction to all five of Herzberg's motivation factors: achievement ( $r=.477)$, recognition $(r=.531)$, growth $(r=.581)$, work itself $(r=.525)$ and promotion $(r=.433)$ at the 0.01 level.

\section{Herzberg's Hygiene Factors}

The correlation matrix of the job satisfaction and Herzberg's hygiene factors illustrate shows that policy $(r$ $=.494)$, relationship with leaders $(r=.552)$, and flight $\operatorname{safety}(r=.531)$ were significantly correlated with job 
satisfaction at the 0.01 level, while relationship with peers $(r$ $=.099)$, work conditions $(r=.266)$ and $\operatorname{pay}(r=.172)$ were not significantly correlated to job satisfaction at the 0.01 level. Work $\operatorname{security}(r=-.101)$ was small negatively correlated and not significance to job satisfaction. Cohen (1988, pp. 79-81) suggests that $r=.10-.29$ small, $r=.30-.49$ medium and $r$ $=.50-1.0$ strong correlation.

\section{Multiple Regression}

TABLE I: RESPONDENTS DEMOGRAPHICS

\begin{tabular}{|c|c|c|}
\hline Respondents' characteristics & Frequencies & Percentages \\
\hline \multicolumn{3}{|l|}{ Gender } \\
\hline Male & 49 & $90.7 \%$ \\
\hline Female & 5 & $9.3 \%$ \\
\hline \multicolumn{3}{|l|}{ Age } \\
\hline $21-30$ & 11 & $20.4 \%$ \\
\hline $31-40$ & 20 & $37.0 \%$ \\
\hline $41-50$ & 20 & $37.0 \%$ \\
\hline$>51$ & 3 & $5.6 \%$ \\
\hline \multicolumn{3}{|l|}{ Rank } \\
\hline Lt. & 6 & $11.1 \%$ \\
\hline Capt. & 9 & $16.7 \%$ \\
\hline Maj. & 36 & $66.7 \%$ \\
\hline $\mathrm{Lt} \mathrm{Col} / \mathrm{Col}$ & 3 & $5.6 \%$ \\
\hline \multicolumn{3}{|l|}{ Academic qualification } \\
\hline STPM & 2 & $3.7 \%$ \\
\hline Diploma & 40 & $74.1 \%$ \\
\hline Degree/Master & 12 & $22.2 \%$ \\
\hline \multicolumn{3}{|l|}{ Years of service } \\
\hline$<10$ & 10 & $18.5 \%$ \\
\hline $10-15$ & 15 & $27.8 \%$ \\
\hline $16-20$ & 13 & $24.1 \%$ \\
\hline$>21$ & 16 & $29.6 \%$ \\
\hline
\end{tabular}

TABLE II: CORRELATIONS BETWEEN JOB SATISFACTION AND HERZBERG'S

\begin{tabular}{|c|c|c|c|c|c|c|c|c|c|c|c|c|}
\hline & Ach & $\operatorname{Rec}$ & Grow & Work & Pol & Peer & Sec & Lead & Cond & Prom & Pay & Flt \\
\hline Job_satis & $.477^{* *}$ & $.531^{* *}$ & $.581^{* *}$ & $.525^{*}$ & $.494^{* *}$ & .099 & $\begin{array}{r}- \\
.101\end{array}$ & $.522^{* *}$ & .266 & $.433^{2 *}$ & .172 & $.531^{* *}$ \\
\hline Achievement & & $.673^{* *}$ & $.548^{* *}$ & $.658^{* *}$ & $.742^{* *}$ & .068 & .047 & $.748^{* *}$ & $.280^{\circ}$ & $.752^{* *}$ & .208 & $.620^{* *}$ \\
\hline Recognition & & & $.576^{* *}$ & $.536^{* *}$ & $.686^{* *}$ & $\begin{array}{r}- \\
.035 \\
\end{array}$ & $\begin{array}{r}- \\
.136 \\
\end{array}$ & $.621^{* *}$ & .105 & $.590^{8 *}$ & .187 & $.590^{* * *}$ \\
\hline Growth & & & & $.411^{* *}$ & $.484^{* *}$ & .087 & $\begin{array}{r}- \\
.003 \\
\end{array}$ & $.442^{* *}$ & .153 & $.379^{* *}$ & .086 & $.377^{* *}$ \\
\hline Work & & & & & $.578^{* *}$ & $\begin{array}{r}- \\
.029 \\
\end{array}$ & $.269^{*}$ & $.642^{* *}$ & .154 & $.568^{8 *}$ & .009 & $.512^{* *}$ \\
\hline Policy & & & & & & .182 & $\begin{array}{r}- \\
.090 \\
\end{array}$ & $.735^{* *}$ & $.343^{*}$ & $.660^{* *}$ & .229 & $.720^{* *}$ \\
\hline Rel_peers & & & & & & & .034 & .111 & .258 & .072 & .152 & .131 \\
\hline work_security & & & & & & & & .019 & $.332^{\circ}$ & .083 & $.283^{*}$ & -.075 \\
\hline Rel_leaders & & & & & & & & & $.360^{* *}$ & $.691 *$ & .174 & $.584 *$ \\
\hline Work_cond & & & & & & & & & & .237 & $.271^{*}$ & $.301^{*}$ \\
\hline Promotion & & & & & & & & & & & $.334^{*}$ & $.606^{* *}$ \\
\hline Pay & & & & & & & & & & & & $.286^{*}$ \\
\hline
\end{tabular}

The results suggested that $40.9 \%$ (adjusted $R$ squared .409 ) of the variance in job satisfaction in the RMAF could be explained by Herzberg's motivation-hygiene theory. The F-ratio of $40.51(p=0.00)$ indicated that the regression model of job satisfaction on the variables assessed was statistically significant. To assess whether the regression analysis suffers from multi-collinearity, the variance inflation factor (VIF) was calculated. Our results shown that all VIF values are less than 5 , indicating there is no multi-collinearity problem in the model. The results in Table III revealed that one of the twelve variables was found to be significant in Navigator context. The analysis demonstrated that the most significant predictors for job satisfaction is career growth $(B=.401, p$ $=.006)$ indicating that Navigator in the RMAF value most the career growth. The evidence concludes that career growth is the most anticipated factor for Navigators.

TABLE III: REGRESSION RESULT FOR HERZBERG'S MOTIVATION-HYGIENE THEORY AND JOB SATISFACTION

\begin{tabular}{|c|c|c|c|c|c|c|c|c|}
\hline \multirow{2}{*}{\multicolumn{2}{|c|}{ Model }} & \multicolumn{2}{|c|}{$\begin{array}{l}\text { Unstandardized } \\
\text { Coefficients }\end{array}$} & \multirow{2}{*}{$\begin{array}{c}\begin{array}{c}\text { Standardized } \\
\text { Coefficients }\end{array} \\
\text { Beta }\end{array}$} & \multirow[t]{2}{*}{ t } & \multirow[t]{2}{*}{ Sig. } & \multicolumn{2}{|c|}{$\begin{array}{c}\text { Collinearity } \\
\text { Statistics }\end{array}$} \\
\hline & & B & $\begin{array}{l}\text { Std. } \\
\text { Error }\end{array}$ & & & & Tolerance & VIF \\
\hline \multirow[t]{13}{*}{1} & (Constant) & -.002 & .842 & & -.003 & .998 & & \\
\hline & achievement & -.189 & 177 & -.228 & 1.068 & .292 & .245 & 4.085 \\
\hline & recognition & .120 & .202 & .105 & .594 & .556 & .358 & 2.792 \\
\hline & growth & . 440 & .150 & .401 & 2.925 & .006 & .593 & 1.686 \\
\hline & work & .168 & .129 & .219 & 1.304 & .200 & .397 & 2.519 \\
\hline & promotion & -.010 & .231 & -.008 & -.044 & .965 & .335 & 2.987 \\
\hline & policy & -.132 & .160 & -.170 & -.826 & .414 & .262 & 3.821 \\
\hline & rel_peers & .013 & .102 & .015 & .132 & .896 & .827 & 1.209 \\
\hline & work_security & -.063 & .114 & -.075 & -.557 & .581 & .617 & 1.620 \\
\hline & rel_leaders & 190 & .135 & 268 & 1.408 & .167 & .308 & 3.251 \\
\hline & work_cond & .116 & .138 & .111 & .843 & .404 & .645 & 1.551 \\
\hline & pay & .069 & .108 & . 079 & .638 & .527 & .733 & 1.363 \\
\hline & flt_safety & .246 & .158 & .255 & 1.563 & .126 & .421 & 2.376 \\
\hline
\end{tabular}

Dependent Variable: job_satisfaction

\section{CONCLUSION AND RECOMMENDATIONS}

The results revealed that all the five tested factors from Herzberg's motivation factors are found to be significant in the context of Navigator in Royal Malaysian Air Force. Achievement, promotion recognition, growth and work itself are strong and positively correlated to Herzberg's motivation factors with job satisfaction. On the other hand, Navigators feel that only 3 Herzberg's hygiene factors can enhance their job satisfaction which are policy, relationship with leaders and flight safety while relationship with peers, work security, work condition and pay were not significantly relevant to their to job satisfaction. Among all the motivation and hygiene factors, career growth emerged as the most significant factor that influence job satisfaction.

The survey results indicated that these Navigators who are mainly holding the rank of Major with an average age of 45, the most experience and talented Navigators in the RMAF. Therefore it is recommended that the organisation formulation of a well-defined and transparent career growth policy for the Navigators. It is to enable personnel to develop their full potential as well as maximising resource efficiency of the organisation. 


\section{REFERENCES}

[1] K. Ahmadi and K. Alireza, "Stress and job satisfaction among air force military pilots," Journal of Social Sciences, vol. 3, no. 3, pp. 159, 2007.

[2] M. A. Khalil, "The relationship between motivation and absenteeism among the staff of the royal Malaysian air force," Master research paper, University of Malaya: Kuala Lumpur, 2010.

[3] M. A. Huselid, "The impact of human resource management practices on turnover, productivity and corporate financial performance," Academy of Management Journal, vol. 38, pp. 635-672, 1995.

[4] RMAF, No 20 Squadron Training Categorisation Instructions, Kuala Lumpur, 2010

[5] RMAF, Human Resource Department annual career progression report, Kuala Lumpur, 2010

[6] RMAF, No.20 Squadron Organizational Chart, Kuala Lumpur, 2010.

[7] RMAF, Human Resource Department annual attrition report, Kuala Lumpur, 2006

[8] F. Herzberg, B. Mausner, and B. B. Snyderman, The Motivation to Work, 2nd Ed., New York: John Wiley and Sons Inc, 1959.

[9] K. N. Gaertner and S. D. Nollen, "Career experiences, perceptions of employment practices, and psychological commitment to the organization," Human Relations, vol. 11, pp. 975-991, 1989.

[10] G. Flynn, "Is your recognition program understood?" Workforce, vol. 77, no. 7, pp. 30-35, 1998.

[11] A. Haslinda and K. Naresh, "Managing employees' career progression: A strategic lever in human resource development," European Journal of Social Sciences, vol. 6, no. 1, pp. 62, 2008.

[12] I. Michalakoukos, P. A. Kostagiolas, G. Alexias, and D. Niakas, "Job satisfaction in substance abuse treatment organisations: Empirical evidence from KETHEA in Greece," International Journal of Behavioural and Healthcare Research, vol. 2, no. 3, pp. 247-264, 2011.

[13] T. Basiron, "A study of job satisfaction among Royal Malaysian Air force air traffic controllers," Master Research Paper, University of Malaya: Kuala Lumpur, 2000.

[14] E. Melero, "Training and promotion: allocation of skills or incentives?" Industrial Relations: A Journal of Economy and Society, vol. 49, no. 4 , pp. 640-667, 2010.

[15] D. Amstel, "Applicability of Herzberg's motivation-hygiene theory to war-zone security contractors," Doctoral thesis, ProQuest, 2008, pp. 126-263.

[16] C. Lillie, "A study of the impact of salary supplements on teacher turnover in North Carolina school districts," North Carolina University, 2009.
[17] C. S. Tan, "A study of job satisfaction among royal Malaysian air force air defence operators," Master research paper, University of Malaya: Kuala Lumpur, 2009

[18] J. E. Ocampo, "Personal motivation of physicians: A study focused on motivation by job enrichment and job satisfaction of public sector physicians in Ecuador," Doctoral dissertation, Capella University, 2010.

[19] H. Sungmin and O. Haemoon, "Reexamination of Herzberg's two-factor theory of motivation in the Korean army foodservice operations," vol. 14, no. 2, pp. 100-121, 2011.

[20] D. Irfan, "An analysis of shift work in the Turkish National Police in light of Herzberg's motivation hygiene theory," $\mathrm{PhD}$ dissertation, Sam Houston State University, 2008.

[21] G. W. Rebok, Y. Qiang, S. P. Baker, and G. Li, "Pilot age and geographic region of commuter and air taxi crashes: A case-control study," Aviation, Space, and Environmental Medicine, vol. 82, no. 2, pp. 111-115, 2011.

[22] G. R. Berent and L. Anderko, "Solving the nurse faculty shortage: Exploring retention issues," Nurse Educator, vol. 36, no. 5, pp. 203-207, 2011.

[23] F.-M. Tan, "Linking career development practices to turnover intention: The mediator of perceived organizational support," Journal of Business and Public Affairs, vol. 2, no. 1, 2008.

[24] M. David and R. Ray, "Performing for pay? The effects of "merit pay' on motivation in a public service," British Journal of Industrial Relations, vol. 32, no. 2, pp. 243-261,1994.

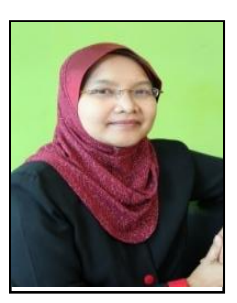

Nurmazilah Mahzan is currently a senior lecturer at Faculty of Business and Accountancy University Malaya, Kuala Lumpur, Malaysia. She obtained her Ph.D. from University of Birmingham, United Kingdom. She also holds professional qualifications of Certified Public Accountant (Malaysia), Certified Internal Auditor and Certified Risk Management and Assurance. She commenced her career with as an external auditor in 1993. She later joined a public listed company as group accounts manager. Her corporate experience covers various industries including property development and construction, banking, unit trusts, trading and manufacturing. In 1999, she left the corporate world for the academia where she embarked on research projects in the areas of corporate governance and accountability. 